\section{Skin Homografts in Parabiotic Mice}

THe failure to obtain successful homografts in nonrelated individuals of the same species is due to antigenic differences occurring between the donor and the recipient on the basis of which the specific immunulogical reaction, transplantation immunity, results. Tissue incompatibility can be overcome either by physical, chemical or biological treatment of the transplant itself diminishing its antigenic diversity in relation to the recipient or by changes in the immunological reactivity of the recipient against the antigens of the transplanted tissues. Hitherto the best method of opposing tissue incompatibility and theoretically the most significant is the experimentally acquired tolerance of the foreign antigens elicited by the action of these antigens on the organism in its early ontogenic stages. This can be accomplished by means of intra-embryonal injections of homologous cells $^{1}$, of injections in new-born animals in the 'adaptative period, 2, by experimental parabiosis in birds ${ }^{3}$ and by exsanguination blood transfusion performed shortly after the birth ${ }^{4}$.

Kamrin and Kamrin ${ }^{5}$ succeoded in provoking a certain degree of organ tolerance in adult mammals by means of parabiosis, and analogous results were described by Nakic and Silobrcic ${ }^{6}$ after skin transplantation between separated rat parabionts.

The purpose of our investigations was to determine the influence, if any, of parabiosis of long duration on the skin homografts in adult non-related mice.

Two series of experiments were performed. In the first one, white mice three months old taken from different nests were united by coelioanastomosis. After $4,5,6$ and 7 weeks of parabiotic union, reciprocal full-thickness skin grafts between the partners were performed. The site of transplantation was the back of the animals. In the second series of experiments males of the inbred strain C57 BI were parabiotically united with females of the same strain. Skin was transplanted between the partners at various periods after their union. In the inbred mice of the strain $C 57 B 1$ skin grafts between males and females always undergo destruction in the course of two weeks which probably depends on the presence of sex antigen in this strain?. The results obtained in the two series are summarized in the Tables 1 and 2 .

During parabiosis of white non-related mice hæmolytic anæmia and the death of the anæmic partner during the first two weeks occurs in about 60 per cent of the cases ${ }^{8}$. Parabionts free of heavier intoxication and the usual subsequent hæmolytic anæmia can be safely kept in parabiosis for more than a year. It was found that in all pairs of white mice remaining in parabiosis for 7 weeks reciprocal 'neutralization' ensues evident in the lack of transplantation im. munity and in the successful homografts. After 6 weeks of parabiotic union skin grafts only took in 50 per cent of the cases. If the parabiosis is of still shorter duration all the skin grafts undergo destruetion at the same time as the grafts performed in control animals, that is, animals not parabiotically united.

In the inbred $C 57 B 1$ mice two weeks of parabiosis was found sufficient to obtain successful skin homografts between males and females. Skin transplants on individuals of two different sexes executed just before or a few days after parabiosis are often followed by initial immunization and intensification of parabiotic intoxication. This agrees with the results obtained during parabiosis of different strains of mice ${ }^{\theta, 10}$.

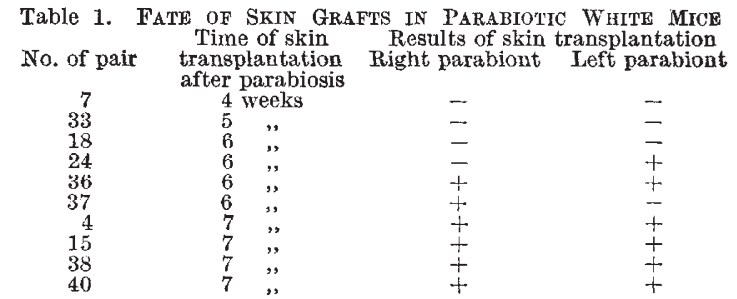

Table 2. Fate of Sigin Grafts in Parabiotic Miof $C 57$ B 1 No. of pair transpiantation Results of skin transplantatio

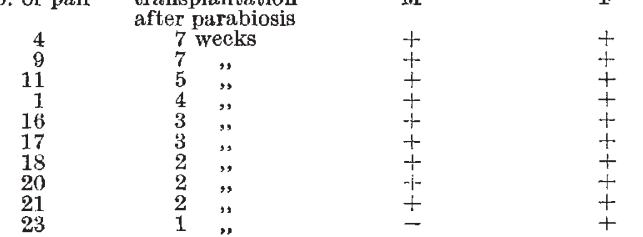

In separated parabionts both of white mice and of mice $C 57 B 1$ none of any destruetive changes in successful grafts were to be observed for 100 days since transplantation.

The results obtained in both series seem to point to the conclusion that the duration of parabiosis necessary for the induction of 'neutralization' depends on the degree of antigenic differences between the parabiotic partners. A detailed account of this work together with the results of researches now in progress relating to the possible mechanism of parabiotic 'neutralization' will be published elsewhere. ANNA SKowron-CEndRzaK Barbara Konieczna-Marczynska

Dept. of Experimental Zoology,

Polish Academy of Sciences,

Kraków, Kopernika 7, Poland. July 28.

1 Billingham, R. E., et al., Nature, 172, 603 (1953).

3 Haskova, V., Folia Biologica, Prague, 3, 129 (1957).

3 Hasek, M., Csl. Biol., 2, 265 (1953). 1 . 182 (1958).

- Kamrin, B. B., and Kamrin, R. P., Anat. Ree., 122, 223 (1955)

Nakic, B., and Silobrcic, V., Nature, 182, 264 (1958)

Eichwald, E. J., et al., Ann. N.Y. Acad. Sci., 64, 737 (1957).

Konieczna-Marczynska, B., and Skowron-Cendrzak, A., Folia Biologica, Krakow (in the press).

Koldovsky, P., and Skowron-Cendrzak, A., Folia Biologica, Prague (in the press).

10 Konieczna-Marczynska, B., and Plonkowa, I., Folia Biologica, Krakow (in the press)

\section{Occurrence of Schoenus nigricans L. on Ombrogenous Peats}

THE seemingly anomalous presence of Schoenus nigricans on Irish blanket peats has often been reported and commented on in the literature ${ }^{1,2,3}$.

The analysis results (Table 1 ) are of waters collected from a raised cupola of peat in south-west Ireland where Schoenus was abundant over the whole area, from the lagg region (modified by cutting) to the pools and hummocks of the apical complex. (For collection and analysis methods see Gorham ${ }^{4}$. Collection was made on January 15, 1959.)

The results indicate the true ombrogenity of the habitat, calcium/magnesium ratio less than unity ${ }^{5}$, a paucity of bases and a $p \mathrm{H}$ considerably lower than that recorded for Schoenus-dominated blanket peats $\left(p\right.$ H. $\left.5 \cdot 18^{5}\right)$.

The presence of this plant in such a habitat is indeed noteworthy and upholds the tentative explanation advanced by Gorham ${ }^{6}$ that "perhaps the mildness of the climate is the factor allowing Schoenus to grow in habitats less base-rich than it commonly frequents 